\title{
MgSIt2, a Cellular Integrity MAP Kinase Gene of the Fungal Wheat Pathogen Mycosphaerella graminicola, Is Dispensable for Penetration but Essential for Invasive Growth
}

\author{
Rahim Mehrabi, ${ }^{1,2}$ Theo van der Lee, ${ }^{1}$ Cees Waalwijk, ${ }^{1}$ and Gert H. J. Kema ${ }^{1}$ \\ ${ }^{1}$ Wageningen University and Research Center, Plant Research International B.V., P.O. Box 16, 6700 AA, Wageningen, \\ The Netherlands; ${ }^{2}$ Agricultural Research \& Education Organization, Seed \& Plant Improvement Institute, \\ P.O. Box 31585-4119, Karaj, Iran
}

Submitted 1 November 2005. Accepted 2 November 2005.

\begin{abstract}
Among expressed sequence tag libraries of Mycosphaerella graminicola isolate IPO323, we identified a full-length cDNA clone with high homology to the mitogen-activated protein (MAP) kinase Slt2 in Saccharomyces cerevisiae. This MAP kinase consists of a 1,242-bp open reading frame, and encodes a 414-amino-acid protein. We designated this homolog MgSlt2, generated MgSlt2 knockout strains in M. graminicola isolate IPO323, and found several altered phenotypes in vitro as well as in planta. In yeast glucose broth, MgSlt2 disruptants showed a defective polarized growth in the tip cells upon aging, causing substantial local enlargements culminating in large swollen cells containing two to four nuclei. The MgSlt2 disruptants showed a significantly increased sensitivity to several fungicides, including miconazole $(2 x)$, bifonazole $(>4 x)$, imazalil $(5 x)$, and cyproconazole $(10 x)$, and were hypersensitive to glucanase. Unlike the wild type, $M g$ Slt 2 disruptants did not produce aerial mycelia and did not melanize on potato dextrose agar. Although cytological analysis in planta showed normal penetration of wheat stomata by the germ tubes of the MgSlt2 disruptants, subsequently formed hyphal filaments frequently were unable to branch out and establish invasive growth resulting in highly reduced virulence, and prevented pycnidia formation. Therefore, we conclude that MgSlt2 is a new pathogenicity factor in M. graminicola.
\end{abstract}

Additional keywords: A. tumefaciens-mediated transformation, Septoria tritici leaf blotch, transposon.

Mycosphaerella is the largest genus in the class Dothideomycetes, an extremely large and diverse class of fungi. With over 1,000 named species, plus its associated asexual stages, the genus Mycosphaerella contains at least 3,000 species and probably is the largest genus of plant pathogens in the fungal

Corresponding author: Gert H. J. Kema; Telephone: +31.317.476149; Fax: +31.317.418094; E-mail: gert.kema@wur.nl

Nucleotide sequence data are available at GenBank under accession numbers bankit718942 or DQ062121. M. graminicola IPO323 is available at the Centraal Bureau voor Schimmelcultures, The Netherlands.

This article is in the public domain and not copyrightable. It may be freely reprinted with customary crediting of the source. The American Phytopathological Society, 2006. kingdom, causing extensive economic losses on a range of crops, including cereals, banana, citrus, soybean, sugar beet, tomato, strawberry, and even tree crops (Farr et al. 1995). Direct losses plus the cost of control strategies contribute to the huge agricultural significance of this genus. The devastating $M y$ cosphaerella fijiensis, causing black leaf streak disease-commonly known as Black Sigatoka disease-in banana headlines the global list of fungicide requirements with an annual volume of U.S.\$2.5 billion. M. citri, the cause of greasy spot of citrus, is the largest fungicide target in this crop in the United States. Septoria tritici leaf blotch is the most important wheat disease in Europe. The causal agent M. graminicola (Fuckel) J. Schröt. is the prime target for the cereal fungicide market, with an estimated annual volume of $\$ 700$ million.

$M$. graminicola is rapidly developing as a model fungus for the order Dothideales (Goodwin et al. 2004). In contrast to other model fungi, such as Magnaporthe grisea (Dean et al. 2005), the penetration of the host by Mycosphaerella spp. occurs indirectly through the stomata. In compatible responses, subsequent development is intercellular, in close contact with mesophyll cells and, depending on the pathosystem, symptomless for 14 to 20 days before rapid cell collapse, suggesting an active role of toxic compounds (Duncan and Howard 2000; Kema et al. 1996d). The resulting necrotic foliar blotches bear numerous pycnidia, the asexual fructifications that contain the splash-born conidia, which are dispersed over short distances within the crop. The symptomatic blotches also contain perithecia, the sexual fruiting bodies that are produced continuously throughout the year, which release the airborne ascospores that travel over large distances within and between wheat crops. These are the propagules that are responsible for early disease establishment and the observed complex genetic structure in natural populations, making Mycosphaerella graminicola population genetics the recognized standard for many other plant pathosystems (Hunter et al. 1999; Kema et al. 1996c; Zhan et al. 2003, 2004; Zhan and McDonald 2004). Early evidence for specificity was controversial; hence, the wheat $-M$. graminicola pathosystem traditionally has been thought to be controlled by quantitative characters in host and pathogen (Eyal et al. 1973, 1985; Johnson 1992; Parlevliet 1993; Van Ginkel and Scharen 1988). It is a testimony to fungal genetics that this hypothesis eventually was falsified and experimental evidence showed that host and pathogen interact according to the gene-for-gene hypothesis (Brading et al. 2002; Kema et al. 1996a,b,c, 2000, 2002; Kema and van Silfhout 1997). Since then, up to eight resistance genes in the host 
were identified and mapped (Adhikari et al. 2003, 2004a,b,c; Arraiano et al. 2001; Brown et al. 2001; Chartrain et al. 2004, 2005). An impressive set of genetic tools has been developed exploiting the genetic tractability of $M$. graminicola (Goodwin et al. 2004). Transformation and targeted gene disruption is highly efficient in this fungus (Adachi et al. 2002; Stergiopoulos et al. 2003; Zwiers and De Waard 2001) and a detailed genetic linkage map is available (Kema et al. 2002). Five ABC transporters have been identified, including $M g A t r 4$, the first pathogenicity factor described in the $M$. graminicola-wheat pathosystem (Stergiopoulos et al. 2002, 2003; Zwiers and De Waard 2000). Recently, we generated over 30,000 expressed sequence tags (ESTs) from a range of cultural conditions (Kema et al. 2003). The genomes of $M$. graminicola and $M$. fijiensis currently are being sequenced at the Joint Genome Institute of the United States Department of Energy.

We recently identified the first $M$. graminicola mitogen-activated protein (MAP) kinase, MgFus3, a homolog of Saccharomyces cerevisiae Fus3, which is required for penetration (Mehrabi et al. 2004). The MAP kinase pathways in eukaryotes represent important processes for the regulation of cell functions (Hirt 1997; Xu 2000). In M. graminicola, MgFus3 is the first representative of this class of genes. To analyze these pathways in detail, we have started a coherent approach to decipher them using the extensive EST resources as well as the genomic sequence that currently is being generated (Kema et al. 2003). MAP kinase pathways, sometimes called extracellular signal-regulated kinase pathways, are well known for their involvement in the transduction of a variety of extra cellular signals. MAP kinases belong to the family of serine/threonine protein kinases and are integral parts of gene cascades generally consisting of three conserved phosphokinases, MAP kinase kinase kinases (MAPKKKs), MAP kinase kinases (MAPKKs), and MAP kinases (MAPKs), that sequentially activate and mediate appropriate cellular responses to specific environmental stimuli (Blumer and Johnson 1994). In the model yeast $S$. cerevisiae, five characterized MAPK pathways were identified that regulate mating, cell wall biosynthesis, pseudohyphal growth, growth under osmostress conditions, and ascospore cell wall formation (Hunter and Plowman 1997). In these pathways, a set of sequentially acting proteins is involved in the transduction of the signals causing activation of serine/threonine MAPK genes (Torres et al. 1991). Transmission of these signals eventually results in the activation of transcription factors that modulate the expression of specific gene sets. In S. cerevisiae, the MAPKs Fus3 and Slt2 control mating and cell wall integrity, respectively (Costigan et al. 1992; Davenport et al. 1995; Elion et al. 1990). Fungal cell walls play diverse roles for fungal growth, development, and stress survival (Kraus et al. 2003). They form an essential barrier protecting cells from external threats, act as morphogenic elements constituting the fungal cell exoskeleton, and, rather than being an inert outer layer, they play a dynamic role in many aspects of fungal physiology (e.g., morphogenesis, metabolite transport, protein secretion, signaling, cell adhesion, and cell-to-cell contact). The most significant components of the fungal cell wall are the polysaccharides chitin and $\beta(1,3)$ D-glucan. These components are absent in higher eukaryotes and, therefore, the fungal cell wall is an attractive target for designing specific antifungal agents with selective toxicity. We are extending our knowledge to unravel the mechanisms that connect fungal cell wall biosynthesis and integrity processes.

In this report, we describe the second MAPK in M. graminicola that we designated as MgSlt2 because it is a homolog of the $S$. cerevisiae Slt2 gene (Torres et al. 1991). We isolated and functionally characterized the role of $\mathrm{MgSlt} 2$ in the dimorphic lifestyle of $M$. graminicola, because hardly anything is known about the relation among pathogenicity, cell growth, and morphogenesis in this important plant-pathogenic fungus.

\section{RESULTS}

MgSlt2 is a homolog of the S. cerevisiae MAP kinase Slt2.

Among EST libraries of $M$. graminicola, we identified a full-length cDNA clone with $62 \%$ identity and $75 \%$ similarity at protein level to Slt2. MgSlt2 possesses a 1,242-bp open reading frame encoding a 414-amino-acid sequence with a calculated molecular weight of $47.6 \mathrm{kDa}$. The protein contains all conserved protein kinase subdomains, including the MAP kinase dual phosphorylation sites TEY (residues 185 to 187) (Fig. 1). Phylogenetic studies revealed that MgSLT2 clusters with SLT2 homologs in the phytopathogenic fungi Magnaporthe grisea, Colletotrichum lagenarium, Claviceps purpurea, Fusarium graminearum, and Blumeria graminis as well as the nonphytopathogenic fungus Emericella nidulans (Fig. 1).

\section{MgSlt 2 is constitutively expressed in planta and in vitro.}

The expression of MgSlt2 was studied, with $\beta$-tubulin as control, by reverse-transcription polymerase chain reaction (RT-PCR) under in vitro and in planta conditions, resulting in a characteristic 757-bp amplification product. The expression pattern was similar for both genes (Fig. 2).

\section{Isolation of $\mathbf{M g S l t} 2$ disruptants.}

Two Mycosphaerella graminicola transformants lacking an intact copy of $M g$ Slt2 (IPO323 $\Delta M g$ Slt2) were identified among 30 hygromycin-resistant transformants by PCR screening using primers $M g S l t 2 \mathrm{~F} 1 / M g S l t 2 \mathrm{R} 1$ (Table 1), designed upstream and downstream of the transposon insertion. Replacement of the original copy of MgSlt2 by the disruption construct was confirmed further by large-size PCR amplification using Herculase DNA polymerase (Fig. 3).

\section{The effect of MgSlt2 on vegetative properties.}

The M. graminicola IPO323 $\Delta M g$ Slt2 disruptants and the wild-type IPO323 strain showed identical growth and maintained the same cell shape and growth rate until 5 days postinoculation (dpi) in fresh yeast glucose broth (YGB) medium. From that point onward, the cells of the IPO323 $\Delta M g$ Slt 2 strains started to show a defect in polarized growth of the tip cells, causing an enlarged and aberrant shape at $7 \mathrm{dpi}$. This defect in cytokinesis eventually resulted in the formation of large and swollen cells at $11 \mathrm{dpi}$ (Fig. 4A). A progressive autolyzing process characterized by swollen cells containing up to four nuclei was revealed by 4',6-diamidino-2-phenylindole (DAPI) staining (Fig. 4B), indicating that, despite hampered cell wall formation, the nuclear division continued. This process started gradually at $11 \mathrm{dpi}$ and continued until massive cell collapse at $18 \mathrm{dpi}$.

The germination frequency of $M$. graminicola IPO323, IPO323 $\Delta M g S l t 2$, and ectopic control strains was similar on potato dextrose agar (PDA) medium (data not shown), and colony shape remained similar until 3 to 4 days after plating. Subsequently, the IPO323 $\Delta M g$ Slt 2 strains grew more slowly, resulting in colonies half the diameter of the wild-type strain IPO323 at 15 dpi. Moreover, IPO323 also produced substantial aerial mycelium that was absent on the IPO323 $\Delta M g$ Slt 2 colonies, even after prolonged growth on PDA (Fig. 5). In addition, M. graminicola IPO323 started to melanize after 4 to $5 \mathrm{dpi}$ and was completely melanized at $11 \mathrm{dpi}$, whereas melanization did not occur in the IPO323 $\Delta M g$ Slt2 strains.

On water agar (1\%), the growth rate of $M$. graminicola IPO323 and the IPO323 $\Delta M g$ Slt 2 strains was similar until 5 dpi, after which the IPO323 $\Delta M g$ Slt 2 strains showed a reduced growth rate resulting in colony sizes half the diameter of the 
wild-type strain IPO323 at 11 days (Fig. 5). In contrast, the colony size and shape of the IPO323 $\Delta M g$ Slt2 strains was similar to IPO323 on E. nidulans minimal medium, but the colony shape of the IPO323 $\Delta M g$ Slt 2 strains appeared less compact, with longer-extending hyphae (Fig. 5).
MgSlt2 is involved in cell wall strengthening and protects the cells from toxic compounds.

We have tested the sensitivity of $M$. graminicola IPO323, IPO323 $\Delta M g S l t 2$, and the ectopic control strains to glucanase, chitinase, and 11 chemical compounds representing several
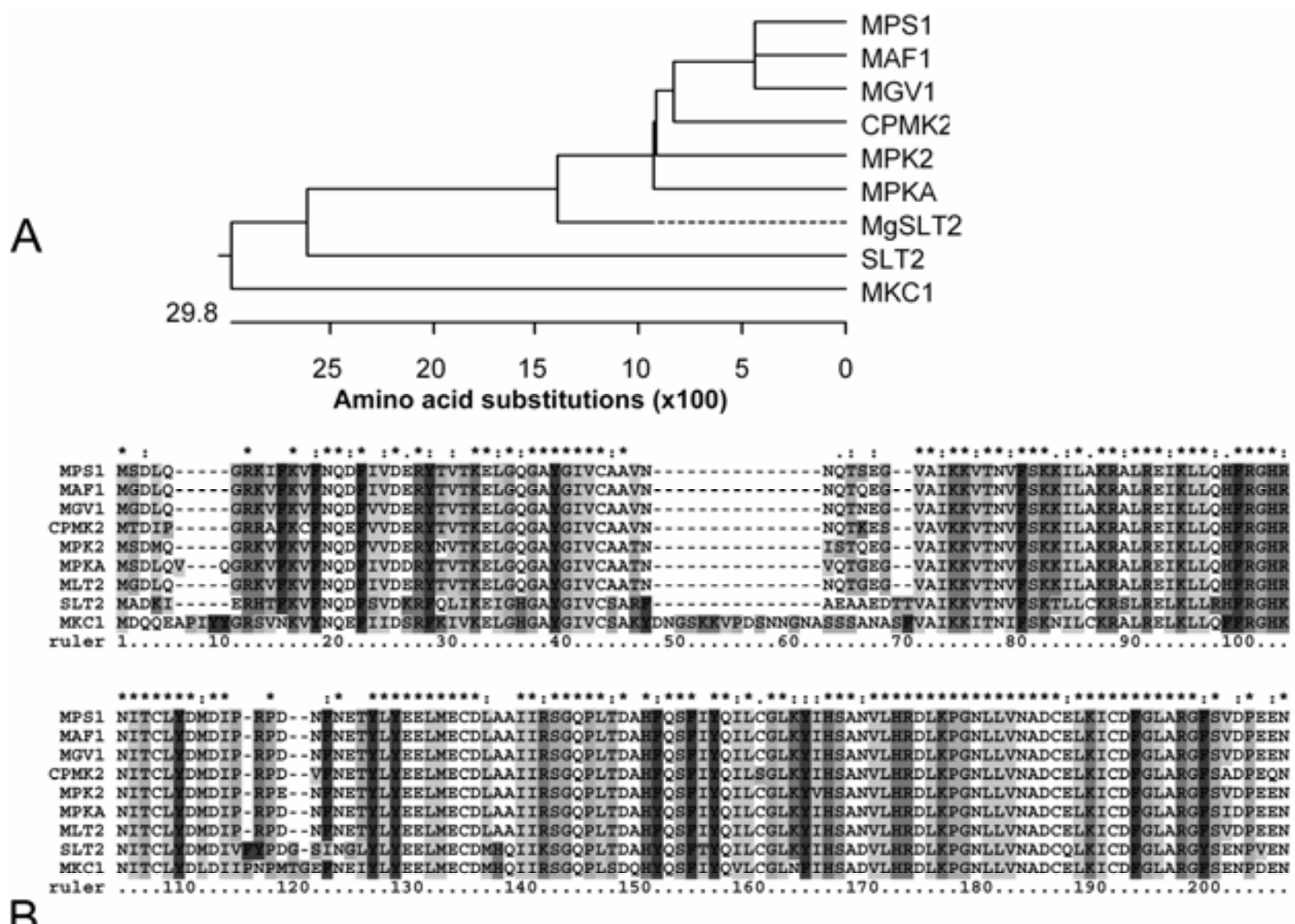

B

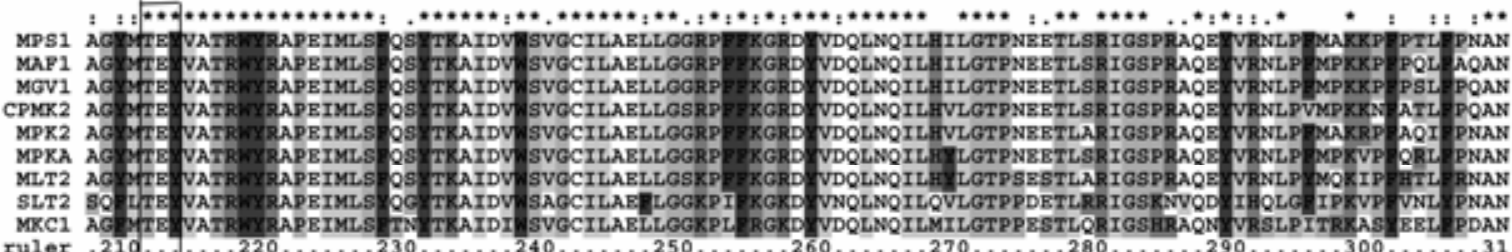

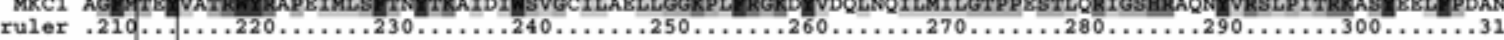
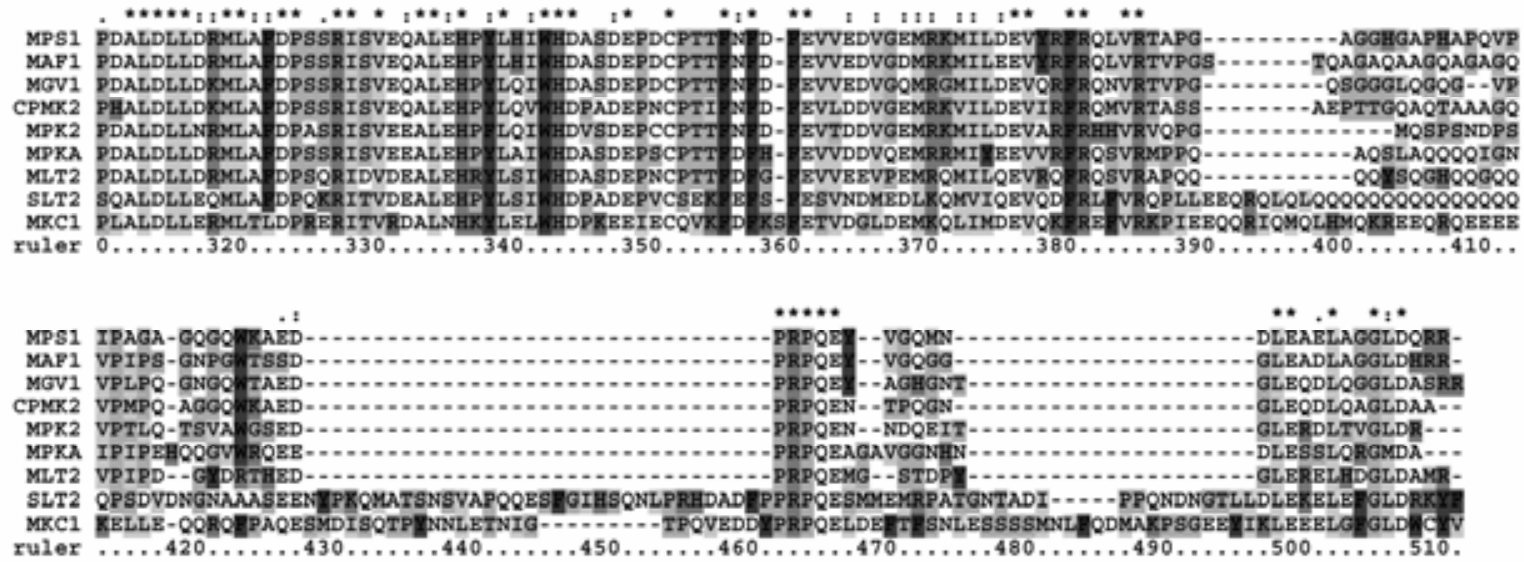

Fig. 1. A, Phylogenetic comparison of MgSLT2 mitogen-activated protein kinase (MAPK) homologues based on amino acid sequence alignments. The deduced peptide sequences of MgSLT2 from Mycosphaerella graminicola was compared with the MAP kinases MPS1 (AF020316) from Magnaporthe grisea, MAF1 (AY064246) from Colletotrichum lagenarium, CPMK2 (AJ320496) from Claviceps purpurea, MPK2 (AF301166) from Blumeria graminis, MGV1(AF492766) from Fusarium graminearum, MPKA (U59214) from Emericella nidulans, SLT2 (X59262) from Saccharomyces cerevisiae, and MKC1 (P43068) from Candida albicans. B, Alignment of the deduced MgSLT2 amino acid sequence with amino acid sequences of MgSLT2 homologues from other related fungi. The conserved dual phosphorylation site TEY in all MAPKs is boxed (residue 185 to 187). Gaps introduced for the alignment are indicated by hyphens. 
classes of fungicides (Table 2). Treatment of the yeast-like spores of IPO323 and the ectopic transformants with glucanase did not show a phenotype, whereas those of the IPO323 $\Delta M g S l t 2$ strains showed (partially) digested cell walls in the majority of cells, leading to significant aggregation after 30

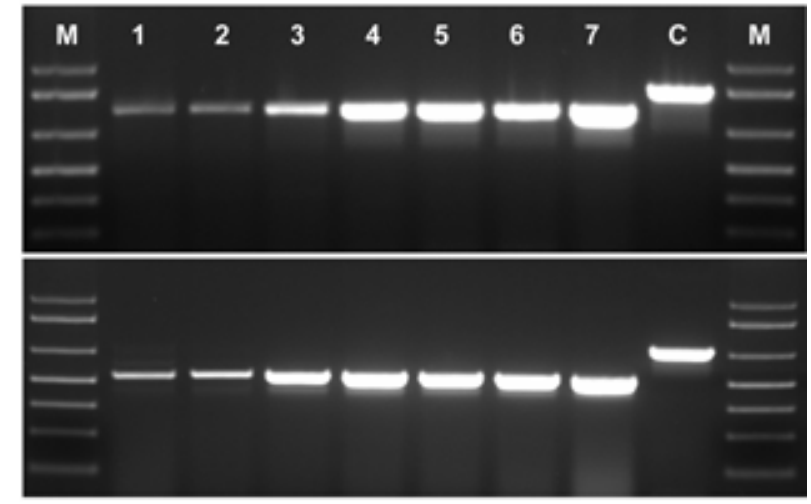

Fig. 2. In vitro and in planta expression analysis of MgSlt2. Reverse-transcription polymerase chain reaction (RT-PCR) products were generated using gene-specific primers for the $\mathrm{MgSlt} 2$ gene (upper panel) and $\beta$-tubulin gene as control (lower panel). Lane M, 1-kb-plus ladder marker. Lanes 1 to 6 , first-strand cDNA generated from total RNA isolated from wheat inoculated with Mycosphaerella graminicola IPO323 harvested at 0, 4, 8, 12,16 , and 20 days postinoculation, respectively. Lane 7, first-strand cDNAs generated from total RNA isolated from M. graminicola IPO323 grown in yeast glucose broth after $100 \mathrm{~h}$. Lane C, PCR control using genomic DNA of M. graminicola IPO323. min of incubation, suggesting hypersensitivity to this compound (Fig. 6). None of the strains was affected by chitinase, even after prolonged incubation ( $24 \mathrm{~h}$; not shown).

We determined the minimum inhibitory concentrations (MICs) of the 11 toxic compounds on yeast-like cells of $M$. graminicola IPO323, IPO323 $\Delta M$ gSlt2, and the ectopic control strains. Compared with IPO323 and the ectopic transformant, the IPO323 $\Delta M g$ Slt 2 disruptants showed a significantly increased sensitivity to miconazole $(2 x)$, bifonazole $(>4 x)$, imazalil $(5 \times)$, and cyproconazole $(10 \times)$ (Table 2). All strains showed a similar sensitivity to cycloheximide, kresoximmethyl, fenpiclonil, trifloxim, berberine, camptothecin, and rhodamine $6 \mathrm{G}$.

\section{MgSlt2 disruptants are highly reduced in virulence.}

In order to determine whether MgSlt2 plays a role in pathogenicity, we compared the pathogenicity of the two independent IPO323 $\Delta M g$ Slt2 strains and both controls (M. graminicola IPO323 and the ectopic transformant) by inoculation experiments on fully unfolded first leaves of the susceptible wheat cv. Obelisk. Both controls already showed small chlorotic flecks at 7 dpi that continued to expand into large areas at 12 dpi and eventually developed into large necrotic areas, especially from the tips of the leaves, containing numerous pycnidia at 16 to $18 \mathrm{dpi}$ (Fig. 7). However, the IPO323 $\mathrm{Mg}$ Slt2-inoculated plants did not develop any symptom until 16 to $18 \mathrm{dpi}$, when limited chlorotic areas developed that gradually increased into larger chlorotic areas at the tips of the leaves, which became necrotic at 20 dpi. Pycnidia never were observed in these limited necrotic areas even after long incubation times when

Table 1. Primers used in this study

\begin{tabular}{lll}
\hline Name & \multicolumn{1}{c}{ Sequence $\left(\mathbf{5}^{\prime}-\mathbf{3}^{\prime}\right)$} & \multicolumn{1}{c}{ Location } \\
\hline$M g S l t 2 \mathrm{R} 1$ & CTCCTCCACAACCTCGAA & $M g S l t 2$ gene \\
$M g S l t 2 \mathrm{~F} 1$ & TGACATGGACATTCCGAGA & MgSlt2 gene \\
Sp6 & TATTTAGGTGACACTATAG & pSport1 border \\
T7 & TAATACGACTCACTATAGGG & pSport1 border \\
PrimerS & ATAATCCTTAAAAACTCCATTTCCACCCCT & Left border of transposon (Tn7L) \\
PrimerN & ACTTTATTGTCATAGTTTAGATCTATTTTG & Right border of transposon (Tn7R) \\
PrimerE & CAGGAAACAGCTATGACATG & Left side of MCS in pCGN1589 \\
PrimerH & GATTAAGTTGGGTAACGCCAGG & Right side of MCS of pCGN1589 \\
\hline
\end{tabular}

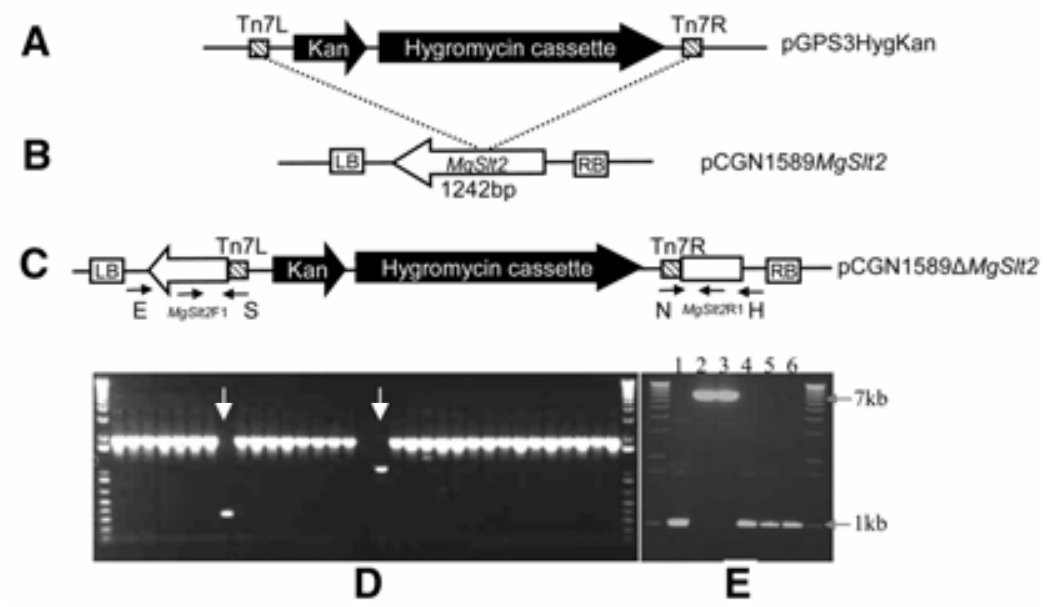

Fig. 3. Diagram of the disruption strategy. A, Customized donor construct (pGPS3HygKan) containing a kanamycin and hygromycin cassette was used for transposition into $\mathbf{B}$, the target construct pCGN1589MgSlt2, resulting in C, the disruption construct pCGN1589 $\Delta \mathrm{MgSlt2}$. The position and the orientation of the insertion were identified using primers located at the end of the transposon (primers $\mathrm{S}$ and $\mathrm{N}$ ) and downstream and upstream of $\Delta M g S l t 2$ (primers $\mathrm{E}$ and H). D, After transposition, the mixture was used to transform Escherichia coli DH10 $\beta$. By screening 32 E. coli colonies in a multiplex colony polymerase chain reaction (PCR) using primers E, $\mathrm{H}$, and $\mathrm{N}$, two colonies containing the transposon in the MgSlt2 gene were identified (indicated by arrows). Constructs with the insertion in the backbone of pCGN1589MgSlt2 show an amplicon size equal to the size of $M g$ Slt2 (approximately $2 \mathrm{~kb}$ ). E, PCR identification of homologous recombinants. The two M. graminicola IPO323 $\triangle M g S l t 2$ disruptant strains that were selected from the first PCR screening were used for largesize PCR amplification using primers MgSlt2F1/MgSlt2R1. Lane 1, M. graminicola IPO323. Lanes 2 and 3, two homologous recombinants IPO323 $\Delta M g S l t 2-$ 1 and IPO323 $\triangle M g S l t 2-2$. Lane 3, 4, and 5, three ectopic transformants. 
physiological chlorosis and necrosis were observed on other parts of these leaves.

\section{MgSlt2 is dispensable for penetration but is essential for invasive growth in wheat leaves.}

To compare the behavior of $M$. graminicola IPO323 and the IPO323 $\Delta M g$ Slt 2 strains in planta, we monitored the infection process over time on the susceptible wheat cv. Obelisk. Examination of growth in planta using traditional staining and light microscopy as well as scanning electron microscopy revealed no significant differences in the germination patterns during the first 4 dpi. The majority of IPO $323 \Delta M g S l t 2$ spores initiated growth and developed germ tubes like IPO323. However, some ( 1 to $5 \%$ ) of the germinated spores showed a shape similar to those that we observed on synthetic media (Fig. 8). Using scanning electron microscopy, we observed that some of these spores or their germ tube initiations had a noncharacteristic shape. However, despite these abnormal phenotypes, these spores eventually were able to develop infectious germ tubes (Figs. 8 and 9A) that entered the wheat leaves through the stomata, similar to the control IPO323. We also observed the characteristic appressorium-like structures, which are dispensable for penetration (Kema et al. 1996d), at the tips of germ tubes that were in contact with the ridges of the stomatal guard cell lips (Fig. 8B). Further evidence for successful penetration of IPO323 $\Delta M g S l t 2$ germ tubes came from infectious hyphae in the substomatal cavities and between mesophyll cells at later stages (Fig. 9D to

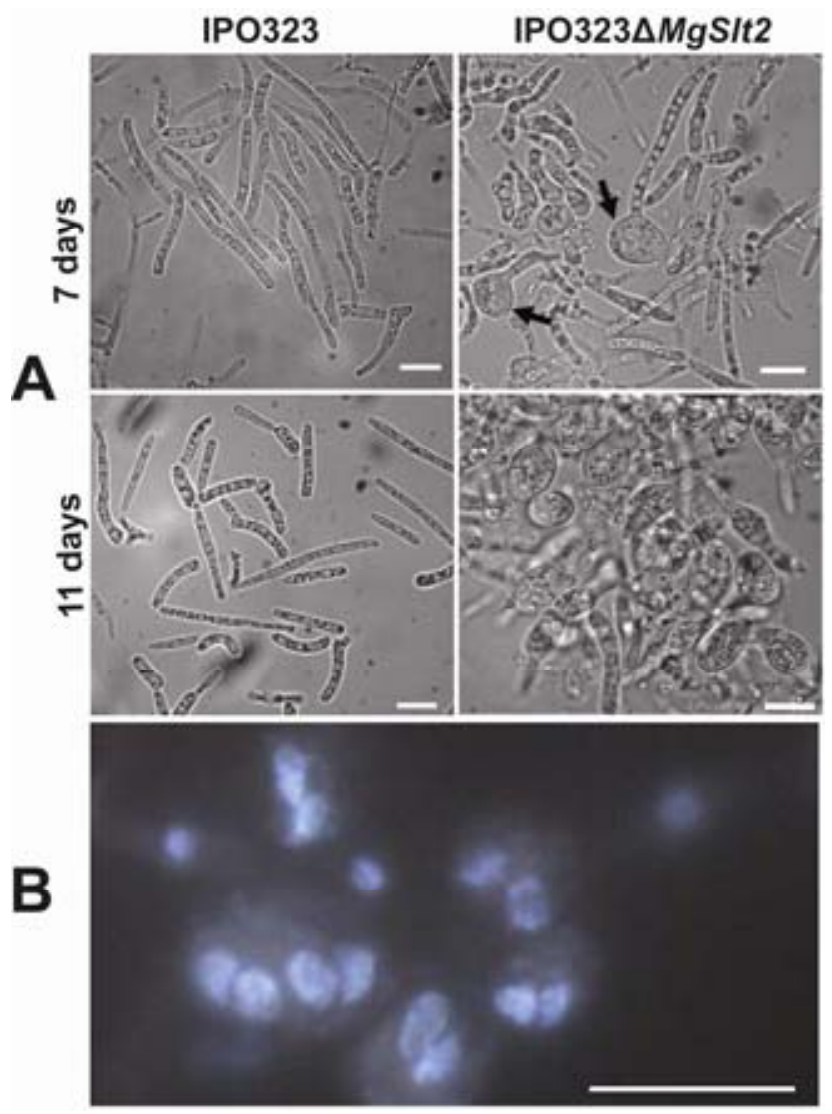

Fig. 4. Effect of MgSlt2 on vegetative reproduction of Mycosphaerella graminicola in yeast glucose broth. A, Progressive autolysis of IPO323 $\Delta M g$ Slt 2 cells compared with the regular cell shape of the wild-type isolate IPO323. Cells show defects in polarized growth in the tip cells (arrows) causing enlarged tips at 7 days, eventually resulting in the formation of large and swollen cells at 11 days. B, 4',6-diamidino-2-phenylindole staining revealed that the swollen cells of IPO323 $\Delta \mathrm{MgSlt} 2$ contained two to four nuclei. Scale bar $=10 \mu \mathrm{m}$.
F). However, unlike IPO323, in which infectious hyphae branched out into invasive mycelium, the IPO323 $\Delta M g$ Slt2 strains failed to do so and never colonized the substomatal cavities and intercellular spaces of the mesophyll (Fig. 9D to F). Further detailed observations revealed that the infectious hyphae of the IPO323 $\Delta \mathrm{MgSlt} 2$ strains had an aberrant shape in close contact with mesophyll cells. The shape and the thickness of IPO323 $\Delta M g S l t 2$ hyphae were similar to IPO323 when growing

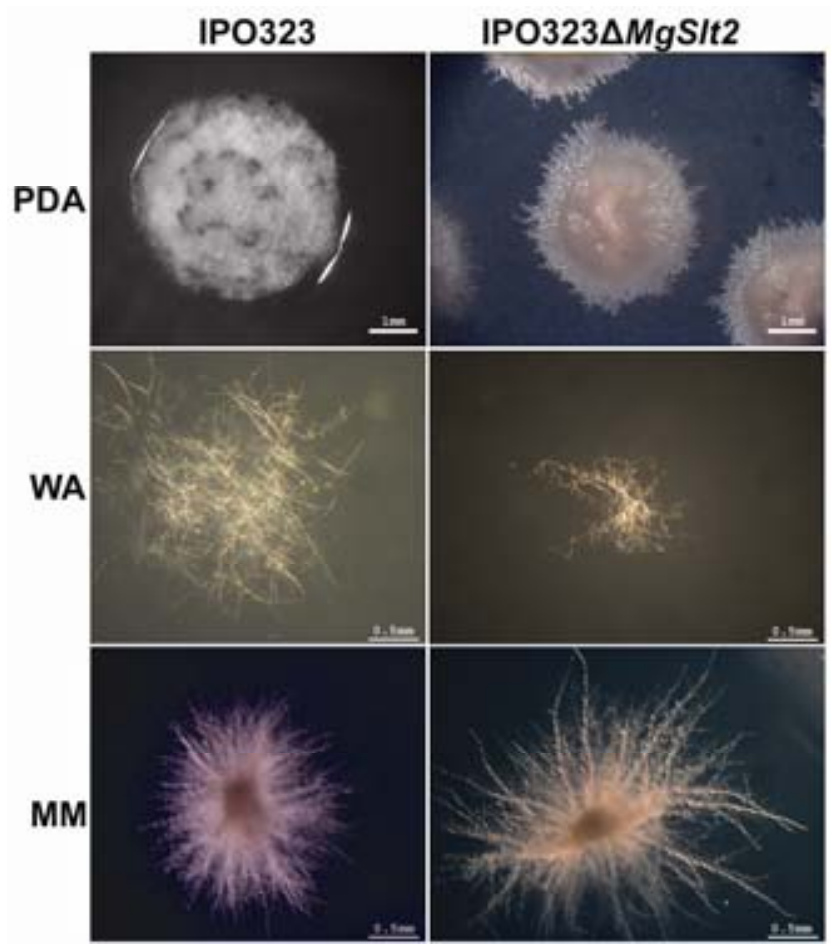

Fig. 5. Effect of $\mathrm{MgSlt} 2$ disruption on morphological characteristics of $M y$ cosphaerella graminicola. Left and right panels show the wild-type isolate M. graminicola IPO323 and the MgSlt2 disruptant, respectively, growing on potato dextrose agar (PDA), water agar (WA), and Emericella nidulans minimal medium $(\mathrm{MM})$ at 11 days at $20^{\circ} \mathrm{C}$.

Table 2. Minimal inhibitory concentrations (MICs) and the derived relative increase of sensitivity $(\mathrm{Q} \text { value })^{\mathrm{a}}$

\begin{tabular}{|c|c|c|c|}
\hline \multirow[b]{2}{*}{ Compounds } & \multicolumn{2}{|c|}{$\operatorname{MIC}(\mu \mathrm{g} / \mathrm{ml})$} & \multirow[b]{2}{*}{$Q$ value } \\
\hline & IPO323 $^{\mathrm{b}}$ & IPO323 $\Delta M g S l t 2^{\mathrm{c}}$ & \\
\hline \multicolumn{4}{|l|}{ Antibiotics } \\
\hline Cycloheximide & 500 & 500 & 1 \\
\hline \multicolumn{4}{|l|}{ Fungicides } \\
\hline Kresoxim-methyl & $>0.25$ & $>0.25$ & 1 \\
\hline Fenpiclonil & 2.5 & 2.5 & 1 \\
\hline Trifloxim & $>0.05$ & $>0.05$ & 1 \\
\hline Miconazole & 0.025 & 0.005 & 2 \\
\hline Bifonazole & 0.1 & $<0.025$ & $>4$ \\
\hline Imazalil & 0.5 & 0.1 & 5 \\
\hline Cyproconazole & 0.5 & 0.05 & 10 \\
\hline \multicolumn{4}{|l|}{ Plant metabolites } \\
\hline Berberine & $>500$ & $>500$ & 1 \\
\hline Camptothecin & $>500$ & $>500$ & 1 \\
\hline \multicolumn{4}{|l|}{ Other } \\
\hline Rhodamine $6 \mathrm{G}$ & 25 & 25 & 1 \\
\hline
\end{tabular}

a (MICs) of 11 compounds that were used in toxicity assays on Mycosphaerella graminicola IPO323 and the disruptant IPO323 $\Delta \mathrm{MgSlt} 2$ strains as well as the derived relative increase of sensitivity ( $Q$ value) of the latter to these compounds

${ }^{\mathrm{b}}$ M. graminicola IPO323 and the ectopic transformant showed similar MIC values.

${ }^{c}$ Both independent IPO323 $\Delta M g$ Slt2 disruptant strains showed similar MIC values. 
in the open space of the apoplast; however, in direct contact with the mesophyll cells, these hyphae were abnormally swollen or collapsed at the contact area (Fig. 9E and F).

\section{DISCUSSION}

We have isolated and characterized $\mathrm{MgSlt}$, a homolog of the Slt2 MAP kinase that regulates cell wall integrity in $S$. cerevisiae. The observed expression pattern was similar to the expression pattern of $\beta$-tubulin; therefore, we conclude that $\mathrm{MgSlt} 2$ is constitutively expressed in planta as well as in vitro. In $M$. graminicola and other fungal pathogens, homologs of the $S$. cerevisiae Fus3 MAP kinase are essential for virulence and other functions (Xu 2000). We recently have shown that disruptants of $\mathrm{MgFus} 3$ are nonpathogenic and demonstrated that this is due to the inability of these mutants to penetrate the stomata of wheat leaves (Mehrabi et al. 2004). In this study, we cloned and characterized $\mathrm{MgSlt2}$, another MAP kinase of $M$. graminicola, and investigated its function in the life cycle and infection process of this important plant pathogen. Slt2 orthologs were functionally characterized in the plant pathogens Magnaporthe grisea, Colletotrichum lagenarium, Claviceps purpurea, and $F$. graminearum, but these have significantly different pathogenic lifestyles and represent an entirely different part of the fungal kingdom (Goodwin 2004; Goodwin et al. 2004). In Colletotrichum lagenarium, MAF1 is required for the

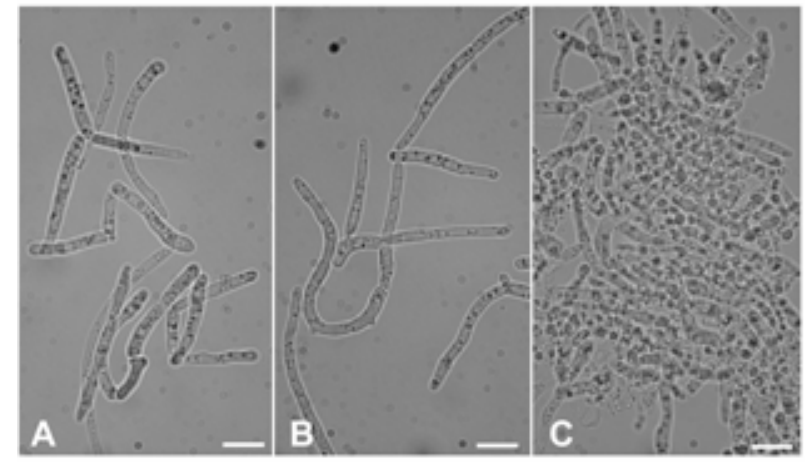

Fig. 6. Sensitivity of MgSlt2 mutants to the cell wall-digesting enzyme glucanase. A, Wild-type strain Mycosphaerella graminicola IPO323 and B, the ectopic transformant did not release many spheroplasts, whereas the cell walls of $\mathbf{C}$, the $M g S l t 2$ disruptant were completely or partially digested under the same conditions. Scale bar $=10 \mu \mathrm{m}$.

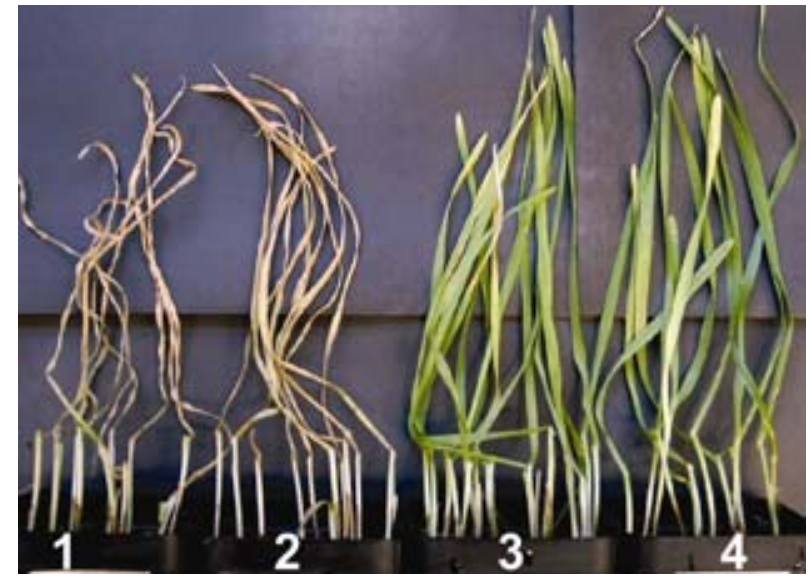

Fig. 7. Effect of the disruption of $M g S l t 2$ on the disease development of Mycosphaerella graminicola on cv. Obelisk 20 days after inoculation. The first leaves were inoculated with the wild-type strain $M$. graminicola IPO323 (1), an ectopic transformant (2), and two independent disruptant strains, IPO323 $\Delta M g$ Slt2-1 (3) and IPO323 $\Delta M g$ Slt2-2(4). early differentiation phase of appressorium formation because mutants failed to form appressoria (Kojima et al. 2002). Contrastingly, mps 1 mutants of Magnaporthe grisea could form appressoria but were nonpathogenic because of the inability of these appressoria to penetrate the plant cell surfaces (Xu et al. 1998). In the non-appressorium-forming fungus Claviceps purpurea, both $C M P K 1$ and $C M P K 2$ are necessary for penetration (Mey et al. 2002). In Mycosphaerella graminicola, MgFus3 is essential for penetration, but MgSlt2 knockouts penetrate equally well as the wild type. Our detailed cytological analysis in planta showed that these attempts resulted in successful penetration because infectious hyphae were present in substomatal cavities and in the intercellular areas of the mesophyll. This suggests that MgSlt2 is not involved in early recognition events. Nevertheless, despite successful penetration, infectious hyphae of IPO323 $\Delta M g$ Slt 2 strains were not able to branch out and colonize the mesophyll. A possible explanation for this observation is that plant metabolites, phytoalexins or pathogenesis-related proteins are detrimental to IPO323 $\Delta M g$ Slt2 and inhibit the growth of infectious hyphae. Thus, as in Magnaporthe grisea, Colletotrichum lagenarium, Claviceps purpurea, and $\mathrm{F}$. graminearum, MgSlt2 affects pathogenicity in Mycosphaerella graminicola, but the mechanism and time frame significantly differ from these other plant pathogens.

Furthermore, conidiation is significantly reduced or even abolished in Magnaporthe grisea, Colletotrichum lagenarium, and Claviceps purpurea, whereas $\mathrm{MgSlt} 2$ knockouts in $\mathrm{My}$ cosphaerella graminicola do not show this defect on either nutrient agar or in liquid culture until aging at a later stage (Kojima et al. 2002; Mey et al. 2002; Xu et al. 1998). This might be an effect of the dimorphism that is recognized in this pathogen which, as such, is intriguing because Slt2 has an effect on budding in $S$. cerevisiae which is not observed in $M$. graminicola (Mazzoni et al. 1993).

Slt 2 homologs also have been cloned and characterized in some non-plant-pathogenic fungi. In S. cerevisiae, the cell integrity Slt2 MAP kinase pathway controls cell-wall integrity and promotes cell-wall remodeling under stress conditions. Slt2 disruptants showed defects in cell-wall integrity, sensitivity to cellwall-degrading enzymes, and an inability to grow at elevated temperatures in the absence of osmotic stabilizers (Costigan et al. 1992; Davenport et al. 1995). Mpkl, the homolog of Slt2 in

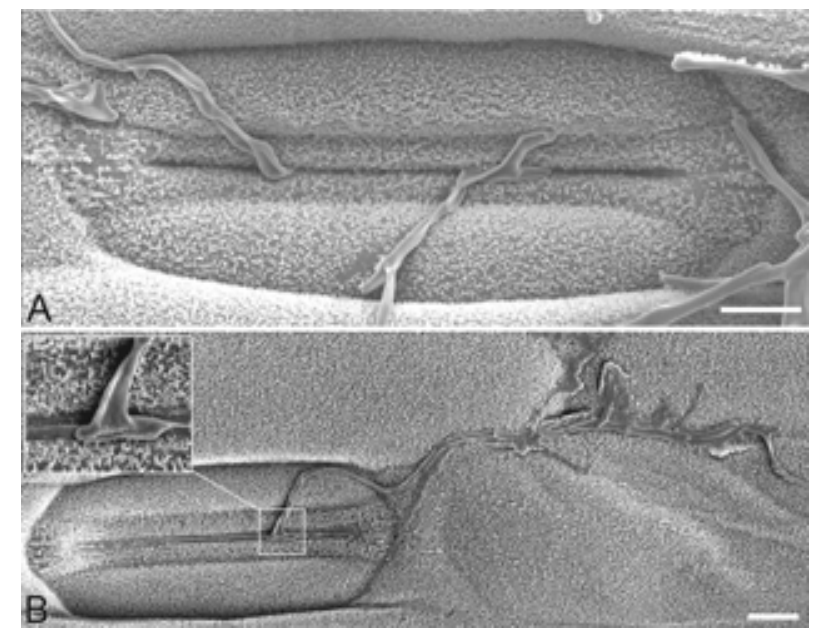

Fig. 8. Scanning electronic microscopy images of Mycosphaerella graminicola penetrating leaves of the susceptible wheat cv. Obelisk at $72 \mathrm{~h}$ postinoculation. A, Penetration of the wild-type strain IPO323. B, Penetration of IPO323 $\Delta M g S l t 2$. The germ tube appears to have a thickened tip (magnification) bending along the stomatal guard cell lips to form an appressorium-like structure. Scale bar $=10 \mu \mathrm{m}$. 
Cryptococcus neoformans, is required for in vitro growth at $37^{\circ} \mathrm{C}$, and the mutants had attenuated virulence in the mouse model of cryptococcosis (Kraus et al. 2003). In E. nidulans, the Slt2 homolog MPKA is involved in spore germination and polarized growth at several stages of colony formation (Bussink and Osmani 1999). The cell-wall aspects of this gene in the abovementioned plant-pathogenic fungi comply partly with our findings. As in Claviceps purpurea, Magnaporthe grisea, and $F$. graminearum (Hou et al. 2002; Mey et al. 2002; Xu et al. 1998), MgSlt2 knockouts of Mycosphaerella graminicola have an increased sensitivity to cell-wall-degrading enzymes and show auto-sphaeroplasting, but still undergo nuclear division. This latter phenomenon was observed and reported only in Slt2ortholog studies in nonpathogenic fungi. Contrastingly, MAF1 did not affect cell-wall strength in Colletotrichum lagenarium as shown by lytic enzyme studies (Kojima et al. 2002). We extended the information on cell-wall integrity aspects of Slt2 orthologs and showed that the IPO323 $\Delta M g$ Slt2 strains also are much more sensitive to a number of fungicides and xenobiotic compounds. We conclusively showed that IPO323 $\Delta M g S l t 2$ strains are more vulnerable to some antifungal compounds than IPO323 and have significantly weaker cell walls than this wildtype strain. Similar results were found by Bahmed and associates (2003), who showed that yeasts without a cell wall were 7 to 20 times more sensitive to amphotericin B, suggesting that they are an important barrier against this compound. Also, the Mpkl mutants in Cryptococcus neoformans displayed enhanced sensitivity to nikkomycin $\mathrm{Z}$ and caspofungin (Kraus et al. 2003). During the infection process, the fungal cell wall is probably under continuous attack by plant defense compounds. In $F$. oxysporum, the overexpression of a cell-wall glycoprotein increased virulence and reduced the sensitivity to the pathogenesis-related protein osmotin (Narasimhan et al. 2003). Our results indicate that $M g S l t 2$ is dispensable for penetration but is essential for in-

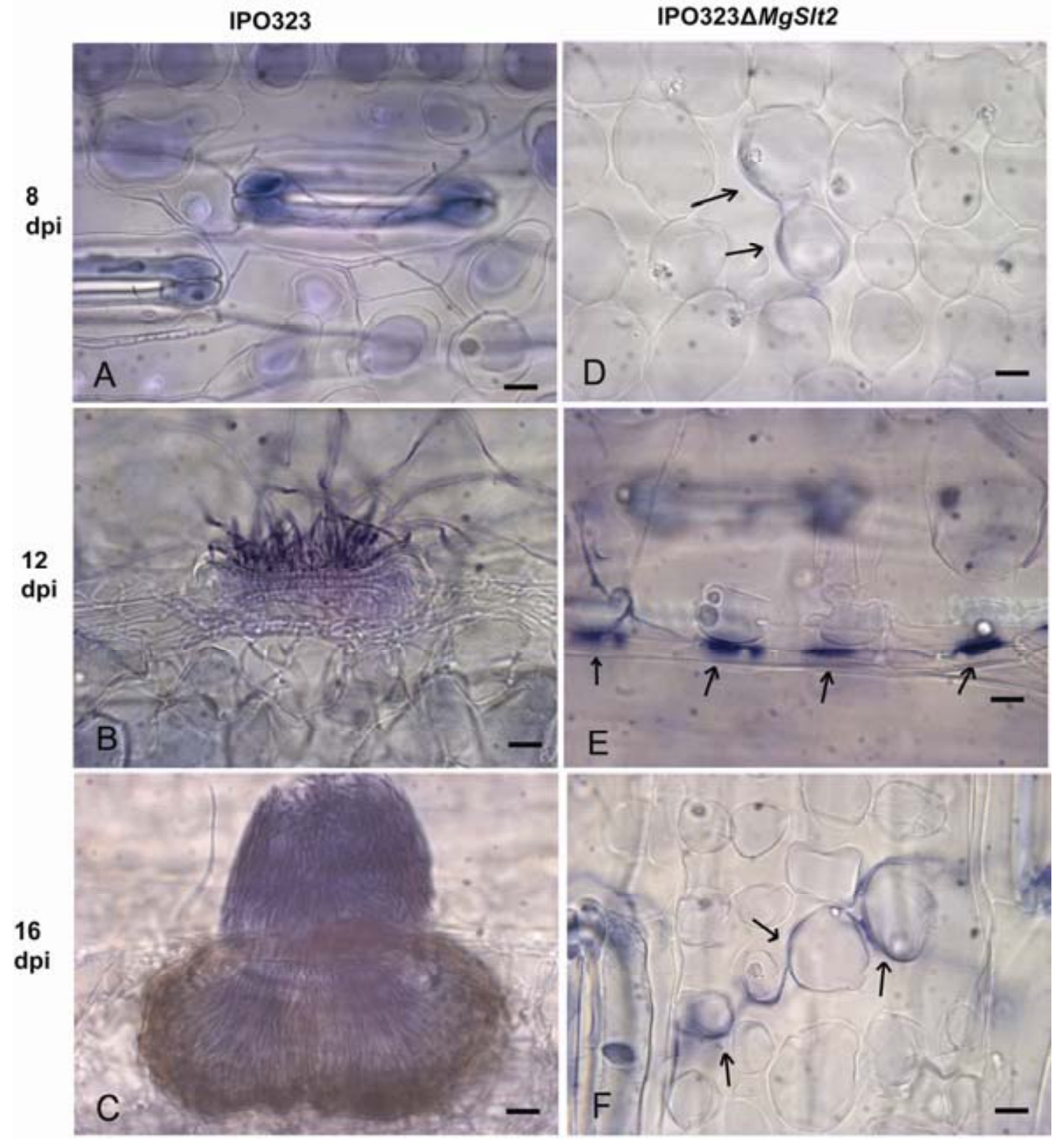

Fig. 9. Comparative pathogenesis of $\mathbf{A}$ through $\mathbf{C}$, Mycosphaerella graminicola IPO323 and $\mathbf{D}$ through $\mathbf{F}$, the disruptant strain IPO $323 \Delta M g S l t 2$ on the susceptible wheat cv. Obelisk at 8,12, and 16 days postinoculation (dpi). A, Penetration of stomates. B, Early pycnidium development in a heavily colonized substomatal cavity. C, Mature pycnidium with exuding cyrrhus, containing the conidia, from the stomatal aperture. D through F, Reduced mesophyll colonization. Hyphae grow in close contact with mesophyll cell walls, and stain intense at later stages (arrows in E and F). Scale bar $=10 \mu \mathrm{m}$. 
vasive hyphal growth. We provided direct evidence that $M g S l t 2$ is involved in cell-wall strengthening, suggesting that the attenuated pathogenicity is due to an increased sensitivity to hitherto unknown plant defense compounds, whose identification is of eminent interest to increase our understanding of the wheat $-M$. graminicola pathosystem.

\section{MATERIALS AND METHODS}

\section{Strains and growth conditions.}

We used M. graminicola IPO323 throughout this study and cultivated it on PDA media (3.9\% [wt/vol] PDA; Difco Laboratories, Detroit, U.S.A.) at $18^{\circ} \mathrm{C}$ to produce yeast-like spores that were collected by gently scraping cultures incubated for 3 to 4 days and subsequently stored at $-80^{\circ} \mathrm{C}$ (Kema and Van Silfhout 1997). M. graminicola IPO323 was grown in YGB ( $1 \%$ yeast extract, $3 \%$ glucose) at $18^{\circ} \mathrm{C}$ in an orbital incubated shaker (Innova 4430; New Brunswick Scientific, Nijmegen, The Netherlands) adjusted to $120 \mathrm{rpm}$ for 5 days to produce inoculum that was collected by centrifugation, washed with water, and adjusted to $10^{7}$ spores per milliliter for inoculation and $10^{8}$ spores per milliliter for transformation. E. nidulans minimal medium was prepared and used based on Barratt and associates (1965) with minor modifications.

\section{DNA manipulation and analysis.}

Basic DNA manipulations were according to standard protocols (Sambrook et al. 1989). Plasmid DNA was isolated using the QIAprep Spin Miniprep Kit (Qiagen, Hilden, Germany). Genomic DNA of $M$. graminicola IPO323 was prepared from freeze-dried spores using the Puregene DNA Isolation Kit (Gentra Systems Inc., Minneapolis). DNA sequences were obtained on an ABI-prism 3100 capillary automated sequencer using the BigDye terminator reaction mix (Applied Biosystems, Amsterdam). Phylogenetic tree generation, DNA and protein sequence alignment, editing, and analysis were performed using MEGALIGN and DNA Star software (Madison, WI, U.S.A.), whereas homology searches were performed with the BLAST program (Altschul et al. 1997) and amino acid sequence alignment was performed using CLUSTAL X (Thompson et al. 1997).

\section{Preparation of disruption construct.}

A full-length $2-\mathrm{kb}$ cDNA clone containing $\mathrm{MgSlt} 2$ was identified in the cDNA libraries of $M$. graminicola IPO323 (Kema et al. 2003). The cDNA insert was excised from the pSport1MgSlt2 plasmid using KpnI/XbaI and cloned into pCGN1589. We used the GPS-Mutagenesis system (New England Biolabs, Leusden, The Netherlands) to make a disruption construct of $M g S l t 2$. A new, customized donor construct was made by insertion of the kanamycin resistance gene into pGPS3Hyg, which previously was described by Zwiers and de Waard (2001). The 1,259-bp kanamycin resistance gene was excised from pGPS3 that was supplied with the kit and inserted into the EcoRV site of pGPS3Hyg, resulting in the new donor construct pGPS3HygKan that was used for transposition. By using two selective markers (hygromycin B and kanamycin) located between the two T7-based transposon borders (T7L and T7R), we were able to select Escherichia coli colonies containing the construct with a copy of the transposon into the target construct, pCGN1589MgSlt2. The target construct pCGN1589MgSlt2 was transposed by the donor construct pGPS3HygKan according to the manufacturer's instructions. The transposition mixture then was cloned to E. coli DH10 $\beta$ that was subsequently grown on selective gentamicin and kanamycin media. A colony PCR was performed by using primerH and primerE (located on the right and left side of the multiple cloning site of pCGN1589, respec- tively) together with PrimerN (located on the Tn7R) in a multiplex colony PCR to identify clones carrying a construct with the insertion of the transposon into the $M g S l t 2$ gene. The PCR was initiated by denaturation at $94^{\circ} \mathrm{C}$ for $3 \mathrm{~min}$; followed by $35 \mathrm{cy}$ cles at $94^{\circ} \mathrm{C}$ for $1 \mathrm{~min}, 57^{\circ} \mathrm{C}$ for $30 \mathrm{~s}$, and $72^{\circ} \mathrm{C}$ for $90 \mathrm{~s}$; with a final extension at $72^{\circ} \mathrm{C}$ for $5 \mathrm{~min}$ and a cooling step to $10^{\circ} \mathrm{C}$. The constructs with the transposon insertion in the backbone of the plasmid (pCGN1589) showed the amplicon size of the cDNA insert, MgSlt2, whereas constructs with the disrupted MgSlt2 generated smaller fragments. We selected a construct (named pCGN1589 $\Delta M g$ Slt2) in which the transposon was inserted almost in the middle of the MgSlt2 open reading frame and determined the exact position of the transposon insertion by sequencing from the right and the left borders of the transposon using PrimerN and PrimerS. Subsequent comparison with the MgSlt2 sequence revealed that the transposon inserted 623 bp downstream of the MgSlt2 starting codon. This construct was used to disrupt $M g$ Slt2 in M. graminicola IPO323 through Agrobacterium tumefaciens-mediated transformation according to Zwiers and de Waard (2001).

\section{Transformation of M. graminicola IPO323 and screening for $\mathrm{MgSlt} 2$ mutants.}

Construct pCGN $\Delta M g S l t 2$ was cloned into A. tumefaciens LBA1100 by electroporation and A. tumefaciens-mediated transformation was carried out according to Zwiers and de Waard (2001). After 3 weeks, individual M. graminicola transformant colonies were collected and transferred to PDA containing hygromycin at $100 \mu \mathrm{g}$ per $\mathrm{ml}$ and cefatoxime at $200 \mu \mathrm{g}$ per $\mathrm{ml}$. The stability of the putative transformants was verified by transferring them three times to fresh PDA medium containing hygromycin at $100 \mu \mathrm{g}$ per $\mathrm{ml}$ and one time to PDA without selection for purification. Finally, a hygromycin-specific PCR was performed to test whether the construct integrated into the genome of the $M$. graminicola IPO323 recipient strain (data not shown). Homologous recombinants were selected by PCR using primers $M g S l t 2 \mathrm{~F} 1$ and MgSlt2R1 (Table 1), which were designed in the flanking regions of the inserted transposon that disrupts the MgSlt2 gene and did not render an amplicon in case homologous recombination took place. Such clones were selected and analyzed using additional large amplification PCR with the same primers (MgSlt2F1 and MgSlt2R1) and Herculase enhanced DNA polymerase (Stratagene, Amsterdam, The Netherlands) according to the manufacturer's instructions.

\section{Sensitivity assay}

to cell wall-degrading enzymes and toxic compounds.

Aliquots of spore suspensions from all $M$. graminicola strains (500 $\mu \mathrm{l}, 10^{7}$ spores per milliliter) were centrifuged and spores were resuspended in either $500 \mu \mathrm{l}(1 \mathrm{mg}$ per $\mathrm{ml})$ of 1,3(1,3:1,4)- $\beta$-D-glucan 3(4) glucanohydrolase (Sigma, Zwijndrecht, The Netherlands) or chitinase $(250 \mu \mathrm{g}$ per $\mathrm{ml})$ (Sigma, Zwijndrecht, The Netherlands) and incubated at 37 and $25^{\circ} \mathrm{C}$, respectively. The activity of the cell wall-degrading enzyme was monitored microscopically every $30 \mathrm{~min}$.

The 11 compounds comprising fungicides, plant metabolites, an antibiotic, and rhodamine $6 \mathrm{G}$ that we used for toxicity assays are listed in Table 2. Spore suspensions $\left(5 \mu \mathrm{l} ; 4 \times 10^{4}\right.$ spores per milliliter) harvested 5 days after inoculating YGB were spotted on 9-cm PDA (39 $\mathrm{g} \mathrm{liter}^{-1}$ ) plates amended with different concentration of these compounds. MICs were assessed for yeast-like cells of M. graminicola IPO323, IPO323 $\Delta M g$ Slt2, and the ectopic control strains after 10 days of incubation at $18^{\circ} \mathrm{C}$ in the dark. The relative increase of sensitivity ( $\mathrm{Q}$ value) of the IPO323 $\Delta M g$ Slt2 strains was calculated by dividing the MIC value of IPO323 by the MIC value of IPO323 $\Delta M g$ Slt 2 . 


\section{Virulence assays.}

Fifteen seeds of the susceptible wheat cv. Obelisk were planted in $5-\mathrm{cm}^{2}$ plastic pots filled with autoclaved soil. The pots were transferred to a compartment providing growth conditions as described previously (Kema et al. 1996a). Ten-dayold seedlings were inoculated by spraying a spore suspension ( $10^{7}$ spores per milliliter) supplemented with $0.15 \%$ Tween 20 as a surfactant. After inoculation, pots were placed in transparent polyethylene boxes ( 6 by 22 by $34 \mathrm{~cm}$ ), incubated at $20^{\circ} \mathrm{C}$ in the dark for $48 \mathrm{~h}$, and subsequently incubated at $16 \mathrm{~h}$ of light $\left(166 \mu \mathrm{E} \mathrm{s}^{-1} \mathrm{~m}^{-2}\right)$ and $8 \mathrm{~h}$ of darkness per day. Disease severity was assayed after $20 \mathrm{dpi}$.

\section{Microscopy.}

Spores of M. graminicola IPO323 produced in YGB were harvested by centrifugation and suspended in fresh YGB at a concentration of 4 to $5 \times 10^{5}$ spores per milliliter. Approximately $200 \mu \mathrm{l}$ of spore suspension was placed on a sterile slide and incubated under humid conditions at $20^{\circ} \mathrm{C}$ for $24 \mathrm{~h}$. Excessive YGB was blotted and slides were immersed in a fixative solution (methanol/acetic acid, 17:3, vol/vol) for $30 \mathrm{~min}$ and flame dried. Samples were stained with DAPI $1 \mathrm{mg}$ per $\mathrm{ml}$ dissolved in anti-fading mounting solution (Johnson and Araujo 1981). Observations were made using an epifluorescence microscope (Zeiss Axioscop, Oberkochen, Germany) equipped with a Nikon CoolSNAP digital camera (RS Photometrics, Roper Scientific Inc., Tucson, AZ, U.S.A.).

Four cytological analysis leaves from inoculated plantlets were harvested and cut into $2-$ to $3-\mathrm{cm}$ segments and immediately immersed in $20 \mathrm{ml}$ of $0.05 \%$ trypan blue dissolved in lactophenol-ethanol (1:2, vol/vol) and boiled for $15 \mathrm{~min}$. Samples were destained overnight in a saturated chloral hydrate solution (5:2, wt/vol), then stored in $87 \%$ glycerol. For light microscopy observations, specimens (adaxial side up) were placed between a glass slide and a cover slip and observed using a Zeiss Axioscop microscope equipped with a Nikon CoolSNAP digital camera.

Scanning electron microscopy was performed to precisely record germination and penetration events. Inoculation and maintenance of the plants was similar to the aforementioned procedures (virulence assays). A small part of the leaf was cut and glued on a sample holder with conductive carbon cement (LeitC; Neubauer Chemicalien, Münster, Germany) and subsequently frozen in liquid nitrogen. The sample was transferred under vacuum to a dedicated cryopreparation chamber (CT $1500 \mathrm{HF}$; Oxford Cryo-System, Eynsham, U.K.) onto a sample stage at $90^{\circ} \mathrm{C}$. Cryofracture was conducted at approximately $-90^{\circ} \mathrm{C}$ using a cold $\left(-196^{\circ} \mathrm{C}\right)$ scalpel blade. The fractured sample was freeze dried for $3 \mathrm{~min}$ at $-90^{\circ} \mathrm{C}$ in vacuum at $3 \times 10^{-7} \mathrm{~Pa}$ to remove water vapor contamination. After the sample surface was sputter coated with $10 \mathrm{~nm}$ of platinum, it was transferred to the cold sample stage $\left(-190^{\circ} \mathrm{C}\right)$ inside the Cryo-FESEM of the scanning electron microscope (JEOL 6300F Field Emission SEM; Tokyo) and subsequently analyzed with an accelerating voltage of $5 \mathrm{kV}$. Images were digitally recorded (Orion, Brussels).

\section{Expression analysis.}

Expression analysis of the MgSlt2 gene was performed in vitro and in planta at different time points using RT-PCR. We collected 10 leaves per sample from inoculated plants that subsequently were flash frozen and ground in liquid nitrogen using a mortar and pestle. Total RNA was extracted from $50 \mathrm{mg}$ of ground leaves using the RNeasy plant mini kit (Qiagen) and potential DNA contamination was removed using the DNAfree kit (Ambion, Cambridgeshire, U.K.), both procedures according to the manufacturer's instructions. First-strand cDNA was conducted using Expand Reverse Transcriptase (Roche Applied Science, Almere, The Netherlands) following the manu- facturer's instructions. PCR reactions were subsequently carried out with $5-\mu \mathrm{l}$ aliquots of this reaction in a $5-\mu \mathrm{l}$ PCR reaction volume, using the same primers and conditions as described above for the detection of homologous recombinants, and amplicons finally were analyzed on $1 \%$ agarose gels using $10-\mu \mathrm{l}$ aliquots of the PCR products.

\section{ACKNOWLEDGMENTS}

R. Mehrabi was financially supported by the Agricultural Research and Education Organization (AREO) of Iran. We thank A. van Aelst, Wageningen Electron Microscopy Center. R. Roohparvar, L.-H. Zwiers, and M. A. de Waard are gratefully acknowledged for technical assistance in performing the toxicity assays. The Dutch Mycosphaerella group, P. J. G. M. de Wit, and J. A. L. van Kan are gratefully acknowledged for discussions and suggestions. Part of this research was funded by Syngenta, Jealott's Hill, U.K.

\section{LITERATURE CITED}

Adachi, K., Nelsen, G. H., Peoples, K. A., Frank, S. A., MontenegroChamorro, M. V., DeZwaan, T. M., Ramamurthy, L., Shuster, J. R., Hamer, L., and Tanzer, M. M. 2002. Efficient gene identification and targeted gene disruption in the wheat blotch fungus Mycosphaerella graminicola using TAGKO. Curr. Genet. 42:123-127.

Adhikari, T. B., Anderson J. M., and Goodwin, S. B. 2003. Identification and molecular mapping of a gene in wheat conferring resistance to $\mathrm{My}$ cosphaerella graminicola. Phytopathology 93:1158-1164.

Adhikari, T. B., Cavaletto J. R., Dubcovsky J., Gieco, J. O., Schlatter, A. R., and Goodwin, S. B. 2004a. Molecular mapping of the Stb4 gene for resistance to Septoria tritici blotch in wheat. Phytopathology 94:11981206.

Adhikari, T. B., Wallwork, H., and Goodwin, S. B. 2004b. Microsatellite markers linked to the Stb2 and Stb3 genes for resistance to Septoria tritici blotch in wheat. Crop Sci. 44:1403-1411.

Adhikari, T. B., Yang, X., Cavaletto, J. R., Hu, X., Buechley, G., Ohm, H. W., Shaner, G., and Goodwin, S. B. 2004c. Molecular mapping of Stb1, a potentially durable gene for resistance to Septoria tritici blotch in wheat. Theor. Appl. Genet. 109:944-953.

Altschul, S. F., Madden, T. L., Schaeffer, A. A., Zhang, J., Zhang, Z., Miller, W., and Lipman, D. J. 1997. Gapped BLAST and PSI-BLAST: A new generation of protein database search programs. Nucleic Acids Res. 25:3389-3402.

Arraiano, L. S., Worland, A. J., Ellerbrook, C., and Brown, J. K. M. 2001 Chromosomal location of a gene for resistance to Septoria tritici blotch (Mycosphaerella graminicola) in the hexaploid wheat "Synthetic 6x". Theor. Appl. Genet. 103:758-764.

Bahmed, K., Bonaly, R., and Coulon, J. 2003. Relation between cell wall chitin content and susceptibility to amphotericin B in Kluyveromyces, Candida and Schizosaccharomyces species. Res. Microbiol. 154:215222.

Barratt, R. W., Johnson, B. G., and Ogata, W. N. 1965. Wild-type and mutant stocks of Aspergillus nidulans. Genetics 52:233-246.

Blumer, K. J., and Johnson, G. L. 1994. Diversity in function and regulation of MAP kinase pathways. Trends Biochem. Sci. 19:236-240.

Brading, P. A., Kema, G. H. J., Verstappen, E. C. P., and Brown, J. K. M. 2002. A gene-for-gene relationship in Septoria tritici blotch of wheat Phytopathology 92:439-445.

Brown, J. K. M., Kema, G. H. J., Forrer, H. R., Verstappen, E. C. P., Arraiano, L. S., Brading, P. A., Foster, E. M., Fried, P. M., and Jenny, E. 2001. Resistance of wheat cultivars and breeding lines to Septoria tritici blotch caused by isolates of Mycosphaerella graminicola in field trials. Plant Pathol. 50:325-38.

Bussink, H. J., and Osmani, S. A. 1999. A mitogen-activated protein kinase (MPKA) is involved in polarized growth in the filamentous fungus, Aspergillus nidulans. FEMS (Fed. Eur. Microbiol. Soc.) Microbiol. Lett. 173:117-125.

Chartrain, L., Brading, P. A., Makepeace, J. C., and Brown, J. K. M. 2004. Sources of resistance to Septoria tritici blotch and implications for wheat breeding. Plant Pathol. 53:454-460

Chartrain, L., Brading, P. A., and Brown, J. K. M. 2005. Presence of the Stb6 gene for resistance to Septoria tritici blotch (Mycosphaerella graminicola) in cultivars used in wheat-breeding programmes worldwide. Plant Pathol. 54:134-143.

Costigan, C., Gehrung, S., and Snyder, M. 1992. A synthetic lethal screen identifies SLK1, a novel protein kinase homolog implicated in yeast cell morphogenesis and cell growth. Mol. Cell Biol. 12:1162-78.

Davenport, K. R., Sohaskey, M., Kamada, Y., Levin, D. E., and Gustin, M. C. 
1995. A second osmosensing signal transduction pathway in yeast: Hypotonic shock activates the PKC1 protein kinase-regulated cell integrity pathway. Journal of Biological Chemistry 270:30157-30161.

Dean, R. A., Talbot, N. J., Ebbole, D. J., Farman, M. F., Mitchell, T. K., Orbach, M. J., Thon, M., Kulkarni, R., Xu, J.-R., Pan, H., Read, N. D., Lee, Y.-H., Carbone, I., Brown, D., Oh, Y. Y., Donofrio, N., Jeong, J. S., Soanes, D. M., Djonovic, S., Kolomiets, E., Rehmeyer, C., Li, W., Harding, M., Kim, S., Lebrun, M.-H., Bohnert, H., Coughlan. S., Butler, J., Calvo, S., Ma, L.-J., Nicol, R., Purcell, S., Nusbaum, C., Galagan, J. E., and Birren, B. W. 2005. The genome sequence of the rice blast fungus Magnaporthe grisea. Nature 434:980-986.

Duncan, K. E., and Howard, R. J. 2000. Cytological analysis of wheat infection by the leaf blotch pathogen Mycosphaerella graminicola. Mycol. Res. 104:1074-1082.

Elion, E. A., Grisafi, P. L., and Fink, G. R. 1990. FUS3 encodes a cdc2+/CDC28-related kinase required for the transition from mitosis into conjugation. Cell. 1990 Feb 23 60(4):649-64.

Eyal, Z., Amiri, Z., and Wahl, I. 1973. Physiologic specialization of Septoria tritici. Phytopathology 63:1087-1091.

Eyal, Z., Scharen, A. L., Huffman, M. D., and Prescott, J. M. 1985. Global insights into the virulence frequencies of Mycosphaerella graminicola. Phytopathology 75:1456-1462.

Farr, D. F., Bills, G. F., Chamuris, G. P., and Rossman, A. Y. 1995. Fungi on Plants and Plant Products in the United States. American Phytopathological Society Press, St. Paul, MN, U.S.A.

Goodwin, S. B. 2004. Minimum phylogenetic coverage: An additional criterion to guide the selection of microbial pathogens for initial genomic sequencing efforts. Phytopathology 94:800-804.

Goodwin, S. B., Waalwijk, C., and Kema, G. H. J. 2004. Genetics and genomics of Mycosphaerella graminicola, a model for the Dothideales. Pages 315-330 in: Applied Mycology and Biotechnology, Volume 4. Fungal Genomics. Elsevier Science B.V., Amsterdam.

Hirt, H. 1997. Multiple roles of MAP kinases in plant signal transduction. Trends Plant Sci. 2:11-15.

Hou, Z., Xue, C., Peng, Y., Katan, T., Kistler, H. C., and Xu, J-R. 2002. A mitogen-activated protein kinase gene $(M G V 1)$ in Fusarium graminearum is required for female fertility, heterokaryon formation, and plant infection. Mol. Plant-Microbe Interact. 15:1119-1127.

Hunter, T., and Plowman, G. D. 1997. The protein kinases of budding yeast: Six score and more. Trends Biochem. Sci. 22:18-22.

Hunter, T., Coker, R. R., and Royle, D. J. 1999. The teleomorph stage, $M y-$ cosphaerella graminicola, in epidemics of Septoria tritici blotch on winter wheat in the UK. Plant Pathol. 48:51-57.

Johnson, G. D., and Araujo, G. M. 1981. A simple method of reducing the fading of immunofluorescence during microscopy. J. Immunol. Methods 43:239-350

Johnson, R. 1992. Past, present and future opportunities in breeding for disease resistance, with examples from wheat. Euphytica 63:3-22.

Kema G. H. J., and Van Silfhout C. H. 1997. Genetic variation for virulence and resistance in the wheat-Mycosphaerella graminicola pathosystem. III. Comparative seedling and adult plant experiments. Phytopathology 87:266-272.

Kema, G. H. J., Annone, J. G., Sayoud, R., van Silfhout, C. H., Van Ginkel, M., and De Bree, J. 1996a. Genetic variation for virulence and resistance in the wheat-Mycosphaerella graminicola pathosystem: I. Interactions between pathogen isolates and host cultivars. Phytopathology $86: 200-212$

Kema, G. H. J., Sayoud, R., Annone, J. G., and van Silfhout, C. H., 1996b. Genetic variation for virulence and resistance in the wheatMycosphaerella graminicola pathosystem. II. Analysis of interactions between pathogen isolates and host cultivars. Phytopathology 86:213220

Kema, G. H. J., Verstappen, E. C. P., Todorova, M., and Waalwijk C. 1996c. Successful crosses and molecular tetrad and progeny analyses demonstrate heterothallism in Mycosphaerella graminicola. Curr. Genet. 30:251-258.

Kema, G. H. J., Yu, D., Rijkenberg, F. H. J., Shaw, M. W., and Baayen, R. P. 1996d. Histology of the pathogenesis of Mycosphaerella graminicola in wheat. Phytopathology 86:777-786.

Kema, G. H. J., Verstappen, E. C. P., and Waalwijk, C. 2000. Avirulence in the wheat Septoria tritici leaf blotch fungus Mycosphaerella graminicola is controlled by a single locus. Mol. Plant-Microbe Interact. 13:1375-1379.

Kema, G. H. J., Goodwin, S. B., Hamza, S., Verstappen, E. C. P., Cavaletto, J. R., Van der Lee, T. A. J., Hagenaar-de Weerdt, M., Bonants, P. J. M., and Waalwijk, C. 2002. A combined AFLP and RAPD genetic linkage map of Mycosphaerella graminicola, the Septoria tritici leaf blotch pathogen of wheat. Genetics 161:1497-1505.

Kema G. H. J., Verstappen, E., van der Lee, T., Mendes, O., Sandbrink, H., Klein-Lankhorst, R., Zwiers, L., Csukai, M., Baker, K., and Waalwijk,
C. 2003. Gene hunting in Mycosphaerella graminicola. Page 252 in: Proc. 22nd Fungal Genet. Conf. Asilomar, CA, U.S.A.

Kojima, K., Kikuchi, T., Takano, Y., Oshiro, E., and Okuno, T. 2002. The mitogen-activated protein kinase gene $M A F 1$ is essential for the early differentiation phase of appressorium formation in Colletotrichum lagenarium. Mol. Plant-Microbe Interact. 15:1268-1276.

Kraus, P. R., Fox, D. S., Cox, G. M., and Heitman, J. 2003. The Cryptococcus neoformans MAP kinase Mpk1 regulates cell integrity in response to antifungal drugs and loss of calcineurin function. Mol. Microbiol. 48:1377-1387.

Mazzoni, C., Zarov, P., Rambourg, A., and Mann, C. 1993. The SLT2 $(M P K 1)$ MAP kinase homolog is involved in polarized cell growth in Saccharomyces cerevisiae. J. Cell. Biol. 123:1821-1833.

Mehrabi, R., Waalwijk, C., van der Lee, T., Ware, S., and Kema, G. H. J. 2004. A MAP kinase gene, $M g M K 1$, is essential for pathogenicity in Mycosphaerella graminicola. Page 75 in: Proc. 7th Eur. Conf. Fungal Genet. Copenhagen, Denmark.

Mey, G., Held, K., Scheffer, J., Tenberge, K. B., and Tudzynski, P. 2002. CPMK2, an SLT2-homologous mitogen-activated protein (MAP) kinase, is essential for pathogenesis of Claviceps purpurea on rye: Evidence for a second conserved pathogenesis-related MAP kinase cascade in phytopathogenic fungi. Mol. Microbiol. 46:305-318.

Narasimhan, M. L., Lee, H., Damsz, B., Singh, N. K., Ibeas, J. I., Matsumoto, T. K., Woloshuk, C. P., and Bressan, R. A. 2003. Overexpression of a cell wall glycoprotein in Fusarium oxysporum increases virulence and resistance to a plant PR-5 protein. Plant J. 36:390-400.

Parlevliet, J. E., 1993. What is durable resistance, a general outline. Pages 23-40 in: Durability of Disease Resistance. Th. Jacobs and J. E. Parlevliet, eds. Kluwer Academic Publishers, Dordrecht, The Netherlands.

Sambrook, J., Fritsch, E. F., and Maniatis, T. 1989. Molecular Cloning: A Laboratory Manual., Cold Spring Harbor Laboratory Press, Cold Spring Harbor, NY, U.S.A.

Stergiopoulos, I., Gielkens, M. M. C., Goodall, S. D., Venema, K., and De Waard, M. A. 2002. Molecular cloning and characterisation of three new ATP-binding cassette transporter genes from the wheat pathogen Mycosphaerella graminicola. Gene 289:141-149.

Stergiopoulos, I., Zwiers L. H., and de Waard M. A. 2003. The ABC transporter MgAtr4 is a virulence factor of Mycosphaerella graminicola that affects colonization of substomatal cavities in wheat leaves. Mol. PlantMicrobe Interact. 16:689-698.

Thompson, J. D., Gibson, T. J., Plewniak, F., Jeanmougin, F., and Higgins, D. G. 1997. The CLUSTAL-X windows interface: Flexible strategies for multiple sequence alignment aided by quality analysis tools. Nucleic Acids Res. 25:4876-4882.

Torres, L., Martin, H., Garcia-Saez, M. I., Arroyo, J., Molina, M., Sanchez, M., and Nombela, C. 1991. A protein kinase gene complements the lytic phenotype of Saccharomyces cerevisiae lyt 2 mutants. Mol. Microbiol. 5:2845-2854.

Van Ginkel, M., and Scharen, A. L. 1988. Host-pathogen relationships of wheat and Septoria tritici. Phytopathology 78:762-766.

$\mathrm{Xu}$, J. R. 2000. MAP kinases in fungal pathogens. Fungal Genet. Biol. 31:137-152.

Xu, J. R., Staiger, C. J., and Hamer, J. E. 1998. Inactivation of the mitogen-activated protein kinase $M p s 1$ from the rice blast fungus prevents penetration of host cells but allows activation of plant defense responses. Proc. Natl. Acad. Sci. U.S.A. 95:12713-12718.

Zhan, J., and McDonald, B. A. 2004. The interaction among evolutionary forces in the pathogenic fungus Mycosphaerella graminicola. Fungal Genet. Biol. 41:590-599.

Zhan, J., Pettway, R. E., and McDonald, B. A. 2003. The global genetic structure of the wheat pathogen Mycosphaerella graminicola is characterized by high nuclear diversity, low mitochondrial diversity, regular recombination, and gene flow. Fungal Genet. Biol. 38:286-297.

Zhan, J., Kema, G. H. J., and McDonald, B. A. 2004. Evidence for natural selection in the mitochondrial genome of Mycosphaerella graminicola. Phytopathology 94:261-267.

Zwiers L. H., and de Waard M. A. 2000. Characterization of the ABC transporter genes MgAtrland MgAtr2 from the wheat pathogen $M y$ cosphaerella graminicola. Fungal Genet. Biol. 30:115-125

Zwiers, L. H., and de Waard, M. A. 2001. Efficient Agrobacterium tumefaciens-mediated gene disruption in the phytopathogen Mycosphaerella graminicola. Curr. Genet. 39:388-393.

\section{AUTHOR-RECOMMENDED INTERNET RESOURCES}

United States Department of Energy-Joint Genome Institute: www.jgi.doe.gov/sequencing/why/CSP2005/mycosphaerella.html

Centraal Bureau voor Schimmelcultures, an institute of the Royal Netherlands Academy of Arts and Sciences: www.cbs.knaw.nl 